\title{
A TRANSFORMATION IN TRAINING: THE FORMATION OF UNIVERSITY MEDICAL FACULTIES IN MANCHESTER, LEEDS, AND LIVERPOOL, 1870-84.
}

\author{
by \\ STELLA V.F. BUTLER*
}

INTRODUCTION

There is little disagreement among historians of British medicine that between 1858, when the Medical Act reached the statute books, and 1900, the profession underwent profound changes. In contrast to the pluralistic structure of the first half of the nineteenth century, the profession greeted the new century in corporate unity. There was still considerable diversity of income among practitioners, but minimal educational standards were in force and all doctors were registered with a central body, the General Medical Council (GMC).

Many aspects of this process of change have yet to be explored. In this essay I focus on the implications of the educational reforms introduced by the GMC after 1858 for professional training in the provinces. Its explicit aim was to raise the standard of medical education and so to improve the social status of the profession. In the larger provincial towns, the reforms in licensing requirements initiated a major institutional restructuring of medical education. Emphasis shifted from apprenticeship towards schools and colleges for professional training. As the curriculum of medical studies became more elaborate, provincial schools looked to the resources of newly-founded university colleges to augment their modest facilities. The development of medical training played a crucial role in the establishment of the British university system, providing links with the professions and ensuring a relatively stable market of students for fledgling colleges. The medical profession in return upgraded the status of its training system and, in so doing, created a structure that would accommodate to major curricular reforms, including the introduction of the biomedical sciences. I shall explore in detail changes in the organization of medical training in Manchester, Leeds, and Liverpool where the relocation of medical education into the local university colleges (which eventually formed the federal Victoria University) involved the setting up of several pre-clinical laboratory-based departments. Full-time chairs in physiology made clinical practice impracticable. These developments mirror events in the United States where medical schools appointed many pre-clinical specialists during a period of rapid growth and reform between 1890 and 1914. Robert Kohler has argued that these changes were integral to the professionalization of American medical practice. In Britain also, the profession sought to underline the "scientific" basis of its authority.

* Stella V.F. Butler, PhD, Greater Manchester Museum of Science and Industry, Liverpool Road Station, Castlefield, Manchester M3 4JP. 
These reforms set in motion changes in other provincial centres, and as a result altered the geographical distribution of students throughout England. By 1900, the domination of London institutions over medical education was on the decline.

The paper is divided into three sections. The first explores the changes in licensing requirements introduced by the Medical Act. The second section details the effects of these reforms on professional training in Manchester, Leeds, and Liverpool and outlines the setting up of the medical faculty of the Victoria University. Developments in other provincial centres are compared in the final section of the paper, together with metropolitan reaction to the upgrading of provincial training.

\section{LEGISLATIVE REFORM IN THE NINETEENTH CENTURY}

Before 1858, when the Medical Act established a legal framework upon which the modern medical profession has evolved, doctors were by no means a monolithic group. ${ }^{1}$ At the apex of the profession a few, highly trained physicians and surgeons commanded considerable fees from the rich. These élite practitioners specialized exclusively in either medicine or surgery. They were usually hospital consultants and enjoyed high social status. The vast majority of practitioners, however, could not afford to specialize, and offered services in all branches of medicine including midwifery. Although some general practitioners were barely distinguishable from physicians or surgeons in terms of their income or the patients they served, many were little more than tradesmen, selling potions across a counter, offering inexpensive medical advice, and performing minor operations.

The lowly status of the main body of the medical profession can be explained, partly, by the licensing requirements set out in the Apothecaries' Act of $1815 .^{2}$ This Act required all those who intended to practise as an apothecary to undergo a five-year training. In legal terms, general practitioners were almost always classified as apothecaries. The association with craft and trade forms of training went a long way to deny general practitioners the status afforded professional men.

From the 1830s, radical general practitioners began to demand reform of this legal framework of medical practice. ${ }^{3}$ Some of those prominent in the movement had trained in Edinburgh, receiving at the university there the most up-to-date training available in Britain. These well-educated practitioners wanted recognition as professional men alongside their hospital colleagues. In particular, they wanted the requirements for apprenticeship abolished.

More generally, all groups within the profession sought a legal monopoly for orthodox practitioners by outlawing heresies such as homeopathy and herbalism. Irvine Loudon's survey has indicated that in 1847 there was a large number of medical men competing for patients. ${ }^{4}$ Restricting the kind of practice permissible was

\footnotetext{
${ }^{1}$ Irvine Loudon, 'Two thousand medical men in 1847', Bull. Soc. soc. Hist. Med., 1983, 33: 4-8. See also, M. Jeanne Peterson, The medical profession in mid-Victorian London, Berkeley and Los Angeles, University of California Press, 1978; Charles Newman, The evolution of medical education in the nineteenth century, Oxford University Press, 1957.

${ }^{2}$ S.W.F. Holloway, 'The Apothecaries' Act, 1815: a reinterpretation', Med. Hist., 1966, 10: 107-129, 221-236.

${ }^{3}$ Ibid., pp.221-236. See also, E. Lee, Remarks upon medical organisation and reform, London, Churchill, 1846, pp.91-93.

${ }^{4}$ Loudon, op. cit., note 1 above.
} 


\section{A transformation in training}

a way of reducing competition. Moreover, establishing a formal entry requirement would allow the profession to control the number of doctors joining its ranks.

Reform proved difficult to achieve because of the many interest groups involved. ${ }^{5}$ The first parliamentary medical reform bill was introduced in 1842 , but legislation abolishing the Apothecaries' Act and establishing the modern form of professional organization did not reach the statute books until 1858. The Medical Act was largely the work of John Simon (1816-1904), Medical Officer to the Privy Council from $1854 .^{6}$ Simon was anxious that doctors appointed to public office should have received adequate training. From 1848, the involvement of medical men in government increased and the disparity between the many professional licences available often made appointing medical officers confusing. Simon aimed to ensure a single standard for medical training, and thus to define clearly what constituted an acceptable practitioner. However, licensing authorities, including the two Royal Colleges, the Society of Apothecaries, and professional associations in Edinburgh and Glasgow, bitterly opposed Simon's proposal for a state licensing examination. Instead, the 1858 Act established a central register to include all licensed practitioners. The Register was to be supervised by a General Council made up of representatives from licensing authorities plus six Crown nominees. ${ }^{7}$ The Council could inspect the examinations of the licensing bodies and advise on the curriculum. Although the Council could not enforce changes in licensing regulations, it could recommend to the Privy Council that certain qualifications were unacceptable for entry on to the Register.

Although the Act did not radically change the structure of medical practice in Britain, it did create conditions for change. The GMC, with power to reject any qualifications regarded as unsuitable for the profession, set about restructuring the form of professional education. By bringing together representatives of all the licensing bodies, reform could be achieved by consensus. ${ }^{8}$ Active Council members made plain that they aimed to improve the quality and hence the status of practitioners generally. As we shall see, the reforms they proposed during the $1860 \mathrm{~s}$ and '70s ensured the transformation of professional training in the provinces.

MEDICAL TRAINING IN MANCHESTER, LEEDS, AND LIVERPOOL AND THE FORMATION OF THE VICTORIA UNIVERSITY

In order to obtain the Licence of the Society of Apothecaries, a compulsory qualification for general practitioners after 1815 , a boy had to be indentured to a recognized practitioner for five years. In addition, the apprentice was required to present several certificates of attendance at certain specified lecture courses. ${ }^{9}$ During the 1820 s and 1830 s, several schools were established by enterprising young practitioners in large provincial towns to cater for the demand from local apprentices

${ }^{5}$ I. Waddington, 'Competition and monopoly in a profession', Amsterdams Sociologisch Tijdsschrift, 1979, 6: 288-321.

${ }^{6}$ Royston Lambert, Sir John Simon, 1816-1904, and English social administration, London, MacGibbon \& Kie, 1963.

${ }^{7}$ Ibid.; see also, W. Pyke-Lees, Centenary of the General Medical Council, 1858-1958, London, GMC, 1959.

${ }^{8}$ D. MacAlister, 'The General Medical Council, its powers and its work', Lancet, 1906, ii: 915-921.

"Minutes of the General Medical Council, 1859, i: 56-59. 


\section{Stella V.F. Butler}

for these prescribed courses. ${ }^{10}$ Usually, apprentices aimed to qualify also with the membership diploma of the Royal College of Surgeons, for which dissecting experience was required. Schools therefore also offered practical classes. Apprentices were not expected to sit any examinations. Schools competed for students on the basis of cost, and teachers could not risk deterring potential customers by threats of high academic standards. Generally, the entire income of these schools was derived from students' fees. There was little capital to invest in elaborate buildings or facilities. In effect, schools were co-operatives of medical teachers, offering the formal instruction required by the major licensing bodies.

When the General Medical Council first considered the state of professional training in 1859 , discussion centred on the standard of general education. ${ }^{11}$ Council members were concerned that there were no entry requirements to ensure a basic standard of numeracy and literacy. In 1860, the Council recommended that all students and apprentices sit a matriculation examination. Throughout the $1860 \mathrm{~s}$ and $1870 \mathrm{~s}$, recommendations were introduced that sought to create an academic foundation of general subjects for professional training. In addition, certain influential Council members, notably E.A. Parkes, ${ }^{12}$ who was involved in redesigning army medical education, believed that apprenticeship was an inappropriate form of training for doctors. In 1862, the Council suggested that medical education should be based on a "four year course of study"13 rather than a five-year apprenticeship. In effect, much more emphasis was being placed on the role of the school in initiating students into the profession.

For medical schools in London the problems of adjusting to more stringent academic standards, and to providing a more comprehensive experience for students, though great, were not insurmountable. Two schools were already part of a college structure, University College and King's College, while the other nine schools were closely associated with large hospitals. ${ }^{14}$ All were, therefore, part of well-established institutions with clearly identifiable traditions. Many of the proposals put forward by the GMC in the 1860 s echoed previous attempts by several London schools to create a collegiate form of professional training. University College in 1828 had put forward a four-year graded curriculum. ${ }^{15}$ Few students enrolled, most preferring the less taxing, established system. In 1842, St Bartholomew's established a residential college in an attempt to foster a studious, responsible attitude among its students. ${ }^{16}$ The proprietary schools in the provinces, on the other hand, offered few opportunities beyond lecture courses. Generally, lecturers were medical practitioners anxious to establish a presence within the local professional hierarchy. Few were committed to teaching for its own sake. Most were

\footnotetext{
${ }^{10} D N B$.

${ }^{11}$ Minutes of the General Medical Council, 1862, i: 72-76.

${ }^{12}$ Stella V.F. Butler, 'Science and the education of doctors in the nineteenth century: a study of British medical schools with particular reference to the uses and development of physiology', PhD, UMIST, 1982, Appendices pp.298-305.

${ }^{13}$ S.W.F. Holloway, 'Medical education in England 1830-1858', History, 1964, 69: 299-324.

${ }^{14}$ Butler, op. cit., note 12 above, p. 20.

${ }^{15} \mathrm{H}$. Hale Bellot, University College London, 1826-1926, London University Press, 1929, p.145.

${ }^{16}$ H.B. Atlay, Sir Henry Wentworth Acland, a memoir, London, 1903, pp.88-89. See also, Stephen Paget, Memoirs and letters of Sir James Paget, London, Longmans Green, 1901.
} 


\section{A transformation in training}

in the early stages of their careers. Although some of the provincial schools boasted close links with local infirmaries, none was integral to these institutions.

However, although the demands made on these schools increased with the Council's insistence on class examinations and higher academic standards, most adjusted to increased enrolments. From the mid-1860s, however, the education committee of the GMC began to put forward suggestions for more radical changes. Committee members such as E.A. Parkes, James Syme, Professor of Clinical Medicine at Edinburgh University, the physiologist, William Sharpey, and others wanted professional training divided into two distinct stages. ${ }^{17}$ The first, or pre-clinical section, would involve dissection classes and study of the sciences that formed the foundation of medical science. After two sessions at a medical school, students would then proceed to hospital practice, through which they would learn the practical aspects of diagnosis and treatment. Council members urged that in the pre-clinical stage, subjects should be taught, wherever possible, through practical classes. These recommendations, which were quickly incorporated into licensing authorities' requirements, caused provincial schools problems. Practical classes needed laboratories. Laboratories were expensive to build, equip, and maintain. Few medical practitioners were able to organize laboratory exercises. Those that were, seldom had the time to devote to this kind of teaching. The medical schools of Nottingham and Hull did not survive these reforms in licensing. Elsewhere, the changes forced medical schools to re-align with other local academic institutions and, as we shall see, the associations thus formed became part of a more fundamental transformation of medical licensing.

In Manchester, for example, the Royal School of Medicine began serious negotiations with the local college of higher education in $1866 .{ }^{18}$ Medical lecture courses had been available to apprentices in Manchester at a variety of schools from 1814. The Royal School of Medicine had been formed in 1822 by Thomas Turner, an ambitious immigrant practitioner, while the Chatham Street School had opened in 1851. The two schools united in 1856 , following an unsuccessful attempt to combine them with Owens College, the recently founded university college. ${ }^{19}$ The college was at a low ebb, attracting few students, and the attempt had failed probably because the college trustees had feared that the balance of power within an extended institution would have fallen to the medical teachers. College officials had also complained about the rowdy and unsavoury reputation of medical students. In 1866, however, the tables were turned and college officials approached the medical teachers with a suggestion that the institutions merge.

During the ten years between the two attempts at amalgamation, Owens College had undergone several important changes. It had opened in 1851 under the terms of the will made by a local hatting merchant, John Owens. ${ }^{20}$ Owens had left a

\footnotetext{
${ }^{17}$ Minutes of the General Medical Council, 1866, 4: 310. See also, E. A. Parkes, 'A scheme of medical tuition', Lancet, 1868, i: 441-443, 473, 502-504.

${ }^{18}$ Minutes of the Trustees for Educational Purposes (of Owens College), 25 January 1866.

${ }^{19} \mathrm{~J}$. Thompson, The Owens College, its foundation and growth, Manchester, 1866, p.149.

${ }^{20}$ Ibid. See also, B.W. Clapp, John Owens, Manchester merchant, Manchester University Press, 1965, p.173. E. Fiddes, Chapters of the history of Owens College and of Manchester University 1851-1914, Manchester University Press, 1937.
} 
considerable fortune to establish a secular institution of higher education for the sons of local middle classes. The trustees appointed through Owens' will had modelled the college on Oxford and Cambridge, placing great emphasis on classics and mathematics. Few students had enrolled, and by the late 1850s, the college was in serious difficulties. ${ }^{21}$ The Trustees had turned to the academic staff for advice and had accepted their suggestions that the academic balance should move towards the sciences and subjects in keeping with local industry. In 1859, they had appointed a young German-trained chemist, Henry E. Roscoe who, together with J.G. Greenwood, the progressive Principal, had begun to transform college teaching. ${ }^{22}$ Roscoe was behind the appointment of Robert Clifton in 1861 to teach practical physics, a subject which Roscoe regarded as an essential complement to his own chemistry classes. By 1866 , the number of students had increased dramatically and the original building was becoming too small to accommodate the various classes. The academic staff seized the opportunity to suggest a major expansion of the institution. ${ }^{23}$ As a result, an "extension movement" was launched to raise funds for new buildings and facilities which would establish the college as the nucleus of a northern university concentrating on the pure and applied sciences ${ }^{24}$

From the minutes of the extension committee, established to co-ordinate the project, it is clear that amalgamation with the medical school was integral to the development of the college. The academic staff noted in 1866 that the prospects of effecting a union between the two institutions had "materially improved" ${ }^{25}$ since the previous attempt at unification. Medical students now had to obtain laboratory instruction in physics, chemistry, and biology, in addition to classes in clinical subjects. Incorporation would swell class numbers as well as forge links with professional education "without... which no college or university seems to have struck deep roots". ${ }^{26}$ Henry Roscoe recommended that extra staff be taken on in college departments which would be most hard pressed by the influx of students. As a result, William Boyd Dawkins, in 1872, became lecturer in geology. In 1874, he became the college's first Professor of Geology. Roscoe undoubtedly modelled Owens College on the system he had experienced in Germany as a student of the chemist, Bunsen. In German universities, academic staff were expected to further their subjects as well as teach students. Medical faculties were an important feature of these institutions, providing highly academic professional training. ${ }^{27}$

Henry Roscoe took a keen interest in the development of the medical faculty. The architect, Alfred Waterhouse, had been commissioned to design a building suitable for a seat of higher learning. He was asked also to design a new medical school. Roscoe went with George Southam, director of the Royal School of Medicine, and several other medical teachers on a tour of London medical schools to investigate all

\footnotetext{
${ }^{21}$ R.Kargon, Science in Victorian Manchester, Manchester University Press, 1978, pp.164-167.

${ }^{22}$ Ibid., pp.169-171.

${ }^{23}$ Minutes of the Trustees for Educational Purposes, 25 January 1866.

${ }^{24}$ W.H. Chaloner, Movement for the extension of Owens College, 1863-1873, Manchester University Press, 1973.

${ }^{25}$ Minutes of College Meetings, 13 January 1866.

${ }^{26}$ Thompson, op. cit., note 19 above, p.419.

${ }^{27} \mathrm{~T}$. Billroth, The medical sciences in the German universities, New York, Macmillan, 1924. 'Science and education in Germany', Nature, 1869, 1: 157-159.
} 


\section{A transformation in training}

that was modern in facilities. ${ }^{28}$ As a result, the medical school provided students not only with extensive dissecting rooms and an anatomical museum but also with several laboratories for physiology and histology. By 1870, these facilities were becoming essential if medical schools were to offer students all the courses required by several of the major licensing authorities, including the Royal College of Surgeons. By joining with Owens College, medical teachers in Manchester were able to accommodate to the changes recommended by the GMC.

The extension movement aimed to raise endowments for academic appointments as well as funding for new facilities. In 1866, the college professors had agreed that it would be "absolutely necessary" to endow one or two full-time chairs in the medical school, both to ensure high standards of education and to establish some degree of parity between medical and other faculties. ${ }^{29}$ In 1871 , when negotiations for incorporation were well under way, the medical professors themselves launched an appeal for funds to provide these additional appointments. Almost immediately, a Miss Brackenbury agreed to give $£ 10,000$ to the appeal. $£ 5,000$ was used to endow a full-time Chair of Physiology. ${ }^{30}$ It is unclear why the endowment went to physiology rather than, say, anatomy. It may be that T.H. Huxley, co-opted on to the medical school committee in March 1873, influenced the decision. It is more likely that Roscoe, impressed by Helmholtz's laboratory at Heidelberg, believed experimental science an important feature of a medical school. The committee appointed an Edinburgh-trained physiological chemist, Arthur Gamgee ${ }^{31}$ and Roscoe may have welcomed the complement to his own subject.

The committee's decision to appoint Gamgee was a major policy departure for the medical school. They maintained that he was "fully qualified to instruct medical students ... and to direct with success the proposed physiological laboratory". ${ }^{2}$ Under the terms of employment Gamgee accepted in 1873, he was expressly forbidden to engage in clinical practice. He was put in charge of a department expected, like other college departments, to produce original research. Unlike his fellow medical teachers, his appointment depended not upon standing within the local professional hierarchy but on stature within a national scientific community. The precedent was of enormous significance, and was followed by similar appointments in several other provincial medical schools. The Manchester Medical School maintained its commitment to full-time pre-clinical teachers, and over the following five years appointed teachers of anatomy and pathology who were encouraged to devote all their energies to the medical school. ${ }^{33}$

The new Manchester Medical School, opened by T.H. Huxley in 1874, offered students facilities unrivalled by any other school in the provinces and superior to most schools in the capital. One of the main motives of the extension movement and, in particular, of establishing a college medical school, had been to obtain for the

\footnotetext{
${ }^{28}$ Proceedings of the Council of the Owens College Extension Committee, 22 March, 1872.

${ }^{29}$ Thompson, op. cit., note 19 above, p.140.

${ }^{30}$ Ibid., p. 247.

${ }^{31}$ For biographical details see Ruth D'Arcy Thompson, The remarkable Gamgees, a story of achievement, Edinburgh, Ramsay Head Press, 1974.

${ }^{32}$ Minutes of College Meetings, 8 May 1873.

${ }^{33}$ Butler, op. cit., note 12 above, pp.133-135, 149-159.
} 
college university status. In 1875 , a campaign to secure a university charter was launched. J.E. Morgan, Professor of Medicine, argued that university status would give more students the opportunity to obtain a medical degree.$^{34}$ However, when, in 1877, the college formally applied to the Privy Council for a university charter, the medical schools of Leeds and Liverpool were vociferous in their opposition to the creation of a university medical school. ${ }^{35}$

In Leeds, a medical school had been established in 1831 by a group of doctors associated with Leeds Infirmary. ${ }^{36}$ The close, though informal, links between the school and the infirmary had continued, the honorary staff of the hospital generally holding appointments at the school. Many of its teachers had played prominent roles in civic affairs. James Williamson, chairman of the school council in 1832, had become one of the early post-reform mayors of the city. Charles Turner Thackrah, another of the original teachers who had previously run an anatomy school for his own pupils, is well known for his investigations into working conditions in factories. ${ }^{37}$ In 1865, with the opening of the new infirmary, the school had also moved into new purpose-built premises close by. However, although during the 1870 s the medical school enjoyed relatively modern facilities, students attended the nearby Yorkshire College of Science for their scientific classes. The college had opened in 1874, following a campaign initiated by local fears of industrial decline. ${ }^{38}$ Several prominent Leeds educationalists argued that Britain's economic future depended upon an efficient system of scientific and technical instruction. If Britain were to compete with the industrial strengths of France and Germany, it was essential that equivalent educational institutions be established in large towns. The Yorkshire College of Science offered classes in physics, chemistry, and geology, subjects directly relevant to industries of the county.

Although one of the prime movers in the setting up of the college, Dr J.D. Heaton, was a prominent local physician and a teacher at the medical school, there were no attempts to include a medical department within the original college. However, the college welcomed medical students to its classes. The first annual report noted that the arrangements with the school over the teaching of chemistry "may be relied upon to admit at least twenty medical students per annum whose fees will necessarily reduce the cost of the chemistry department". ${ }^{39}$ In fact, medical students greatly outnumbered the college chemistry students. From 1876, the college also offered biology classes. Medical students began to take advantage of this instruction in 1878 , increasing the size of the class dramatically. Whereas in $1877 / 8$ there had been only eleven students studying biology, the addition of twenty-six medical students the following session boosted the number to forty. ${ }^{40}$

\footnotetext{
${ }^{34} \mathrm{~J}$.E. Morgan, Medical education at the universities, Manchester, 1875; idem, Why are there no medical degrees?, Manchester, 1881.

${ }^{35}$ Minutes of the Council of the Leeds Medical School, 10 July 1879. Minutes of the Liverpool Infirmary Medical School, 3 September 1877; 12 June 1879; 3 July 1879.

${ }^{36}$ S.T. Anning, The General Infirmary at Leeds, London, Livingstone, 1963, vol. 1, pp.51-55; vol. 2, 1966, pp. 84-90.

${ }^{37} \mathrm{~A}$. Meiklejohn, The life, work and times of Charles Turner Thackrah, 1795-1833, Edinburgh, Livingstone, 1957.

${ }^{38}$ A.N. Shimin, The University of Leeds, the first half century, Cambridge University Press, 1954.

${ }^{39}$ Annual report of the Yorkshire College of Science, 1875/6, p.11.
} 


\section{A transformation in training}

The college in its early years clearly gained greatly from the stability afforded by the steady enrolment of a sizeable body of medical students. The medical school, in turn, received the advantages of well-qualified science teachers for its students, without the necessity to surrender its independence. The college was controlled by a board of lay governors. Academic staff had little control over policy. The medical school, on the other hand, was entirely owned and run by its teachers. As we shall see, it was only when Owens College seemed likely to grant licences to practise that the medical school considered a closer association with the Yorkshire College desirable.

The Liverpool Infirmary Medical School had been founded in $1833 .{ }^{41}$ As in Leeds, the school developed close links with the local infirmary. Although in the early decades of the school, students were never numerous, in the late sixties, there had been a rapid increase in enrolments and, by 1871 , it was clear that an extension of the premises was necessary if the school were to cope. Mitchell Banks, who later was to achieve great distinction as an anatomist, had suggested that additional facilities be funded through a public appeal. ${ }^{42}$ The money raised was sufficient to build laboratories on to the existing school. Nevertheless, by the end of the decade, it was clear that more drastic steps were necessary if the school was to continue to compete successfully with Owens College for students.

The difficulty became acute when, in 1876, London University amended its degree regulations and required laboratory instruction in physics as part of the preliminary medical course. No one among the medical school staff was qualified to offer such classes. In September 1877, only a month after the teachers had drafted their first statement of opposition to the Owens College charter, the medical professors met to discuss what action they should take. Initially, they decided to appeal for public support to endow a Chair of Physics within the medical school. However, James Campbell Brown, Professor of Chemistry at the Medical School, suggested they broaden the proposal to encompass a college of higher education. ${ }^{43}$ The teachers therefore approached the Association for the Promotion of Higher Education in Liverpool, who, from 1874, had been responsible for organizing the Cambridge University Extension lectures in the city. When the two groups met, they agreed that a university in Liverpool would be useful and launched a public campaign for funds. The appeal soon became an issue of civic pride and was promoted by the mayor. ${ }^{44} \mathrm{As}$ in Leeds, the medical teachers, though deeply involved in the project, were not anxious that their school become a college faculty. Although they perceived clear advantages in establishing an institution capable of providing scientific teaching of high academic standard, they were clearly reluctant to surrender their independence to a lay-controlled endowed college. Nevertheless, in Liverpool especially, medical teachers supported the endowment of academic facilities because it was thus possible for them to match the facilities being developed for students in nearby Manchester.

\footnotetext{
${ }^{40}$ Ibid., 1878/9, p.13.

${ }^{41}$ Lord Cohen of Birkenhead, 'The Liverpool Medical School and its physicians (1642-1934)', Med. Hist., 1972, 16: 310-320.

${ }^{42}$ Minutes of the Liverpool Medical School, 31 May 1871; 12 July 1871.

${ }^{43} \mathrm{~J}$. Campbell Brown, The first page in the history of University College, Liverpool, Liverpool, 1907, pp. 11-12.

${ }^{44}$ Ibid., p. 17. E.F. Rathbone, William Rathbone, a memoir, London, Macmillan, 1905, pp. 225-363. T. Kelly, For the advancement of learning: the University of Liverpool, Liverpool University Press, 1981.
} 


\section{Stella V. F. Butler}

The loose associations between the medical schools in Leeds and Liverpool and their respective university colleges illustrate the changing nature of professional training in the 1870 s. The proprietary schools in provincial towns did not have the capital reserves to finance the expensive facilities and full-time appointments required to teach the curriculum being developed in response to GMC recommendations. In turn, the schools provided a solid foundation for the establishment of higher education. Nevertheless, the moves by Owens College to secure university status and thus the right to grant licences to practise created a totally new situation. Not only would Owens College Medical School gain considerable status and prestige as a university faculty, but its teachers, as university lecturers, would be able to set their own degree curriculum. They would no longer simply respond to the teaching requirements set by the Royal College of Surgeons, the Royal College of Physicians, and the Society of Apothecaries, but would take part in the debates through which the professional curriculum was laid down. Owens College medical teachers would also become examiners of one of the profession's higher qualifications, the medical degree. The vehement protests of the Leeds and Liverpool medical teachers, who argued that there was no need to create a further licensing authority in England, were heeded by the Privy Council, who granted Owens College a charter in 1880 , but denied the university the right to award medical degrees. ${ }^{45}$ Opposition from Leeds and Liverpool also secured their own future. The charter created a federal university; Owens was simply its first college.

Medical teachers in both Leeds and Liverpool realized that it would be only a matter of time before Owens College was given the right to award medical degrees. In 1882, the Royal Commission investigating the working of the 1858 Medical Act and its amendments, recommended that more facilities should be created to enable students in England to obtain medical degrees. In Scotland, there had long been a tradition of university medical training. The vast majority of graduate practitioners in Britain during the 1870 s had obtained their degrees north of the border. In England, by contrast, there was little professional instruction offered at the two ancient universities, where complicated statutes made long periods of residence necessary; at London University, the MB was a daunting test of academic ability. The Commission specifically recommended that the Owens College charter be extended to include the medical faculty. ${ }^{46}$

The Yorkshire College, anxious to become part of the federal northern university, approached the medical school in 1882, urging the staff to consider full amalgamation. Negotiation was slow and complicated, revealing the academic ambitions the medical school professors nursed for their institution. The Yorkshire College had originally offered only scientific instruction. Such a narrowly based institution was unlikely to achieve university status. Clifford Allbutt, later Regius Professor of Physic at Cambridge, wrote to the College council on behalf of his medical school colleagues outlining their "grave misgivings". ${ }^{47}$ Unless the college gained university status, "the medical school would derive no advantage from the

\footnotetext{
${ }^{45}$ Fiddes, op. cit., note 20 above, p.104.

${ }^{46}$ Royal Commission appointed to Inquire into the Medical Acts, 1882, (Cd 3259-I) xxix, p.xiii.

${ }^{47}$ Minutes of the Council of the Leeds Medical School, 21 May 1883.
} 


\section{A transformation in training}

union which would compensate for the loss of its independence and self government". The college council anxiously reassured the medical teachers of their plans for the college and agreed that a medical faculty would retain a large degree of autonomy. As in Manchester, all parties agreed that there should be at least one endowed full-time appointment in the medical school. In August 1883, the medical teachers launched an appeal for funds to endow a Chair of Physiology. ${ }^{48}$ Members of the profession as well as previous college benefactors gave generously, and the salary of the professor was guaranteed at $£ 300$ per annum, the sum decided upon ten years previously as that required "to obtain the services of eminent scientific men". The terms of the appointment were similar to those set for the Manchester Chair. The Professor was not permitted to take on any clinical commitments. ${ }^{49}$ As in Manchester, the Chair went to someone outside the Leeds professional community. A. de Burgh Birch ${ }^{50}$ who, like Arthur Gamgee, had studied at Edinburgh University. The ambitions of the academic staff of the united college were fulfilled when, in 1887, the Yorkshire College was admitted to the Victoria University.

University College Liverpool opened in 1882. Initially, the medical school remained separate. Its students nevertheless attended the classes provided by William Herdman, Professor of Natural History, Oliver Lodge, Professor of Physics, and James Campbell Brown, Professor of Chemistry. Almost immediately, it became clear that Owens College would be given the right to award medical degrees and that full amalgamation was therefore imperative. The first Annual Report noted that "nothing but this . . can save the Medical School from grave injury, if not complete destruction". ${ }^{51}$ The medical teachers readily agreed to re-form themselves as a college faculty. Although in Liverpool there was no insistence on the endowment of a full-time Chair in Physiology, the medical teachers nevertheless ensured that their faculty was associated with scientific instruction and research. The scientific professors (of physics, of chemistry, and of natural history) were included as members of the medical faculty, ensuring several full-time members of staff with national reputations for their work. The college's subsequent petition to join the federal university structure was successful and, in 1884, University College Liverpool gained the same status as Owens College within the Victoria University.

\section{THE CONSEQUENCES OF REFORM}

The precedents set by the formation of the Victoria University were of enormous importance in the development of the national pattern of medical education. Those proprietary medical schools which had survived into the 1880 s all took advantage of the facilities offered at their neighbouring university college. In Birmingham, students from the Queen's Medical School attended Mason College from its opening in $1875 .^{52}$ The two institutions amalgamated in 1892 in order to achieve university

\footnotetext{
${ }^{48}$ Minutes of the Council of the Leeds Medical School, 23 August 1883. Subscription list given in the Benefaction Book of the Leeds Medical School. There is no indication, however, as to whether the list is complete.

${ }^{49}$ Minutes of the Council of the Yorkshire College, 10 June 1884.

${ }^{50}$ Biographical details taken from Medical Directories and Leeds Medical School records.

${ }^{51}$ Annual report of University College, Liverpool, 1882.

${ }^{52}$ History of the Birmingham Medical School 1825-1925, Special number of the Birmingham Medical Review, December 1925, pp.44-45.
} 


\section{Stella V. F. Butler}

status. In Bristol, doctors from the medical school were active in the movement to establish a university there in $1874 ;^{53}$ the medical school became a college faculty in 1893. Firth College, Sheffield (founded in 1874) and the local medical school enjoyed a close association from the 1880 s. $^{54}$ In 1895 , the two institutions amalgamated in order to apply for membership of the Victoria University. In Newcastle also, the Infirmary school became part of the university college when the college sought chartered status. ${ }^{55}$

The associations (and subsequent amalgamations) between medical schools and colleges were of enormous significance to the colleges. Diagram I and Table I indicate the relative proportion of medical students in the colleges of the Victoria University from their foundation until 1914. The relationships were symbiotic: the proprietary schools, which enjoyed limited facilities, gained prestige from the culture and learning of the colleges, as well as the use of laboratories provided through educational philanthropy. In this way, schools were able to offer students the more sophisticated curriculum which began to develop after 1870 . By the 1880 s, teachers were encouraged both by the GMC and by licensing authorities to teach wherever possible through practical instruction. It is significant that those provincial medical schools that did accommodate these demands placed upon their teaching resources after 1860 all became university faculties.

There can be little doubt that by 1900 the opportunities provincial schools offered would-be doctors more nearly matched those offered by metropolitan institutions than in 1860. The increasing attractiveness of provincial schools was reflected in the distribution of students matriculating for professional courses. Diagram II demonstrates that the London schools were losing ground to the provincial schools throughout the last two decades of the century. By the 1890s, the numbers of students attending the eleven schools of the capital were beginning to decrease in absolute terms.

There were several reasons why, in many cases, provincial schools were becoming more attractive than London institutions. The cost of living in the capital has always been significantly higher than in less sophisticated provincial cities. ${ }^{56}$ Moreover, by 1900 , several of the provincial medical schools enjoyed university status. The degree has always been the more distinguished qualification, denoting the doctor's academic abilities and hence his potential for consultant status. By attending a university medical faculty rather than a hospital school, students increased their chances of obtaining that coveted academic award. Access to medical degrees was a major issue in the campaign to reform the structure of London University in the 1880 s and $1890 \mathrm{~s}^{57}$ Indeed, the campaign was largely stimulated by doctors' concern at the power of the Victoria University to award degrees. London University reformers argued that the failure rate in London MB examinations was very high because of the distance between examiners and teachers. It was only with the reorganization of

${ }^{53}$ F.R. Cross, 'Early medical teaching in Bristol: the Bristol Medical School and its association with the University', Br. med. chir. J., 1927, 44: 73-112.

${ }^{54} \mathrm{~A}$. W. Chapman, The story of a modern university, Oxford University Press, 1955, pp. 13-14, $118-148$.

${ }^{55} \mathrm{C}$. Grey Turner, The Newcastle upon Tyne School of Medicine, 1834-1934,Newcastle, 1934.

${ }^{56}$ E.H. Hunt, Regional wage variations 1850-1914, Oxford University Press, 1973.

${ }^{57}$ Butler, op. cit., note 12 above, pp.171-207. 


\section{A transformation in training}

London University in 1900 that teachers in the hospital medical schools gained some influence through Boards of Study over the structuring of the curricula and the setting of examinations. Even then, the cumbersome administrative structure of the university meant that innovations were slow to affect the examination system. As a result, the London degree continued to be a difficult academic hurdle for the majority of students well into the twentieth century. DIAGRAM I. GRAPHS TO SHOW AVERAGES OF STUDENTS FOR APPROXIMATELY FIVE-YEAR PERIODS IN THE COLLEGES
OF THE VICTORIA UNIVERSITY, 1851-1914.

(i) Owens College. Manchester

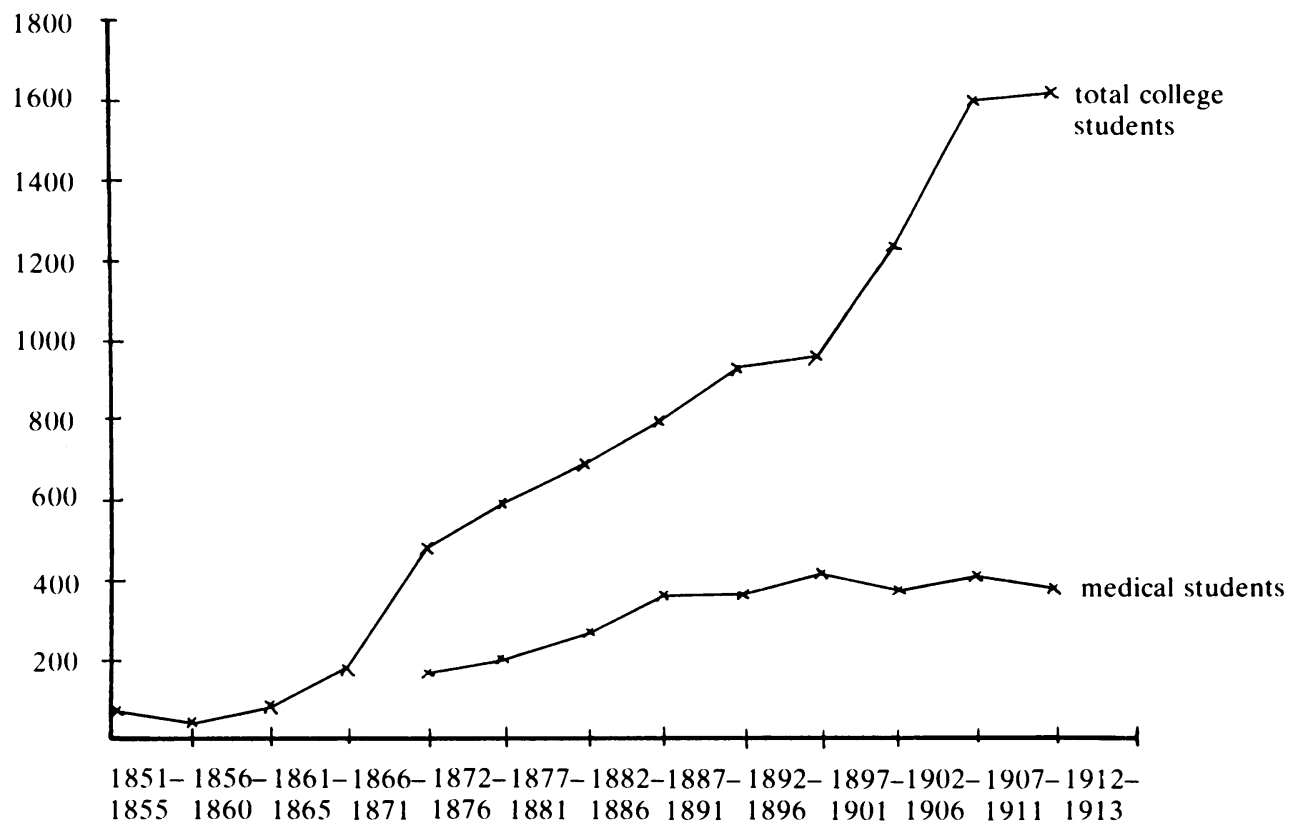

(ii) Yorkshire College, Leeds

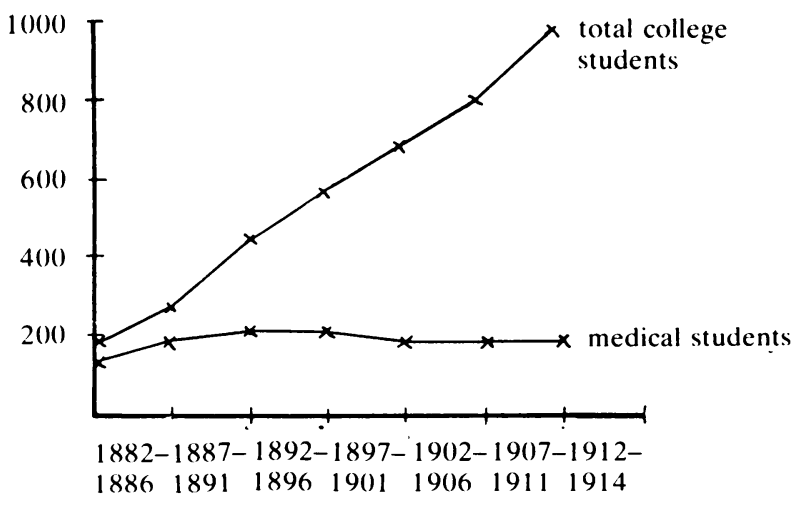




\section{Stella V. F. Butler}

(iii) University College Liverpool

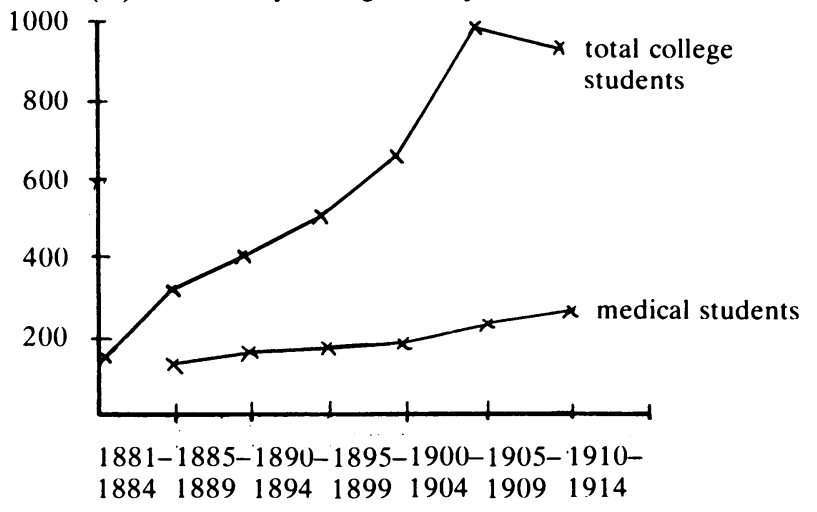

TABLE I. PERCENTAGE OF MEDiCAL STUDENTS AMONG TOTAL COLLEGE STUDENTS IN THE COLLEGES OF THE VICTORIA UNIVERSITY $1851-1914$

(i) Owens College, Manchester

$\begin{array}{lllll}\text { Period } & \begin{array}{l}\text { Average } \\ \text { total }\end{array} & \begin{array}{l}\text { Average } \\ \text { medicine }\end{array} & \begin{array}{l}\text { Average } \\ \text { non-medicine }\end{array} & \begin{array}{l}\% \\ \text { of }\end{array} \\ 1851-2 / 1855-6 & 63 & - & 63 & - \\ 1856-7 / 1860-1 & 47 & - & 47 & - \\ 1861-2 / 1865-6^{*} & 109 & - & 109 & - \\ 1866-7 / 1871-2 & 216 & - & 216 & - \\ 1872-3 / 1876-7 & 520 & 144 & 376 & 28 \\ 1877-8 / 1881-2 & 620 & 208 & 412 & 34 \\ 1882-3 / 1886-7 & 707 & 334 & 431 & 39 \\ 1887-8 / 1891-2 & 827 & 336 & 493 & 40 \\ 1892-3 / 1896-7 & 961 & 352 & 635 & 35 \\ 1897-8 / 1901-2 & 996 & 335 & 644 & 35 \\ 1902-3 / 1906-7 & 1,277 & 352 & 942 & 26 \\ 1907-8 / 1911-2 & 1,617 & 339 & 1,265 & 22 \\ 1912-3 / 1913-4^{* *} & 1,659 & & 1,320 & 20\end{array}$

${ }^{*}$ Figures refer to six sessions not five

**Figures refer to two sessions not five

(ii) Yorkshire College, Leeds.

$\begin{array}{lllll}\text { Period } & \begin{array}{l}\text { Average } \\ \text { total }\end{array} & \begin{array}{l}\text { Average } \\ \text { medicine }\end{array} & \begin{array}{l}\text { Average } \\ \text { non-medicine }\end{array} & \begin{array}{l}\% \text { Medicine } \\ \text { of total }\end{array} \\ 1882-3 / 1886-7 & 190 & 125 & 65 & 66 \\ 1887-8 / 1891-2 & 278 & 185 & 93 & 67 \\ 1892-3 / 1896-7 & 458 & 204 & 254 & 44 \\ 1897-8 / 1901-2 & 559 & 179 & 380 & 32 \\ 1902-3 / 1906-7 & 684 & 150 & 534 & 22 \\ 1907-8 / 1911-2 & 803 & 150 & 653 & 19 \\ 1912-3 / 1913-4^{*} & 947 & 150 & 797 & 16\end{array}$

*Figures refer to two sessions not five. 


\section{A transformation in training}

(iii) University College Liverpool

$\begin{array}{lllll}\text { Period } & \begin{array}{l}\text { Average } \\ \text { total }\end{array} & \begin{array}{l}\text { Average } \\ \text { medicine }\end{array} & \begin{array}{l}\text { Average } \\ \text { non-medicine }\end{array} & \begin{array}{l}\text { \%edicine } \\ \text { of total }\end{array} \\ 1881-2 / 1884-5^{*} & 132 & - & 132 & - \\ 1885-6 / 1889-90 & 318 & 134 & 184 & 42 \\ 1890-1 / 1894-5 & 412 & 152 & 260 & 63 \\ 1895-6 / 1899-00 & 523 & 170 & 383 & 31 \\ 1900-1 / 1904-5 & 653 & 176 & 477 & 27 \\ 1905-6 / 1909-10 & 1,004 & 242 & 862 & 24 \\ 1910-1 / 1913-14 & 929 & 280 & 649 & 30\end{array}$

${ }^{*}$ Figures refer to four sessions not five.

The formation of university medical faculties in the provinces involved in each case the endowment of the pre-clinical sciences. Often schools followed the precedent set in Manchester and appointed full-time physiology teachers. A full-time professor was appointed at Bristol in 1899 as part of the modernization of the medical school following its amalgamation with the university college. ${ }^{58}$ In Liverpool in 1891, concern over the lack of a full-time medical teacher and worries about the scientific reputation of the faculty led to the endowment of a full-time Chair of Physiology. ${ }^{59}$ The first professor was Francis Gotch.$^{60}$ His successor, who took up his appointment in 1895 , was the outstanding neurobiologist, Charles Sherrington. ${ }^{61}$ The shipowner, George Holt, endowed this Chair, and in 1895, provided further funds for a full-time Professor of Pathology. At the same time, Lord Derby endowed a Chair of Anatomy, and plans for a new block of laboratories were finalized. ${ }^{62}$ When Sheffield Medical School and Firth College merged, there were clearly high hopes that full university status would be achieved. Major reforms within the medical faculty were necessary, however, before the college was granted a royal charter. New school buildings were erected; a full-time Chair of Pathology established; a full-time lecturer in physiology appointed. The reorganized school could then boast extensive laboratories as well as well-qualified staff with national reputations. ${ }^{63}$

By 1900 , there was, therefore, a significant number of full-time pre-clinical appointments in medical schools throughout Britain. As a result, research careers in several of the biomedical sciences became possible, especially in physiology. Although few of the provincial departments achieved distinction in these fields, the appointments were necessary to establish a national network and ensure a lively academic community. The endowments for these full-time appointments often involved public appeals for funds. It is clear that doctors, and particularly medical

\footnotetext{
${ }^{58}$ Cross, op. cit., note 53 above, p.50.

${ }^{60}$ Obituary', Br. med. J., 1913, ii: 153-203.

${ }^{61} \mathrm{~J}$. Swazey, Reflexes and motor integration: Sherrington's concept of integrative action, Boston, Mass., Harvard University Press, 1969.

${ }^{62}$ Annual Report of University College, Liverpool, 1894.

${ }^{63}$ W.S. Porter, The Medical School in Sheffield, 1828-1928, Sheffield, 1928, pp.93-94.
} 
Stella V.F. Butler

DIAGRAM II. NUMBER OF MEDICAL STUDENTS REGISTERING IN ENGLAND, 1880-1909

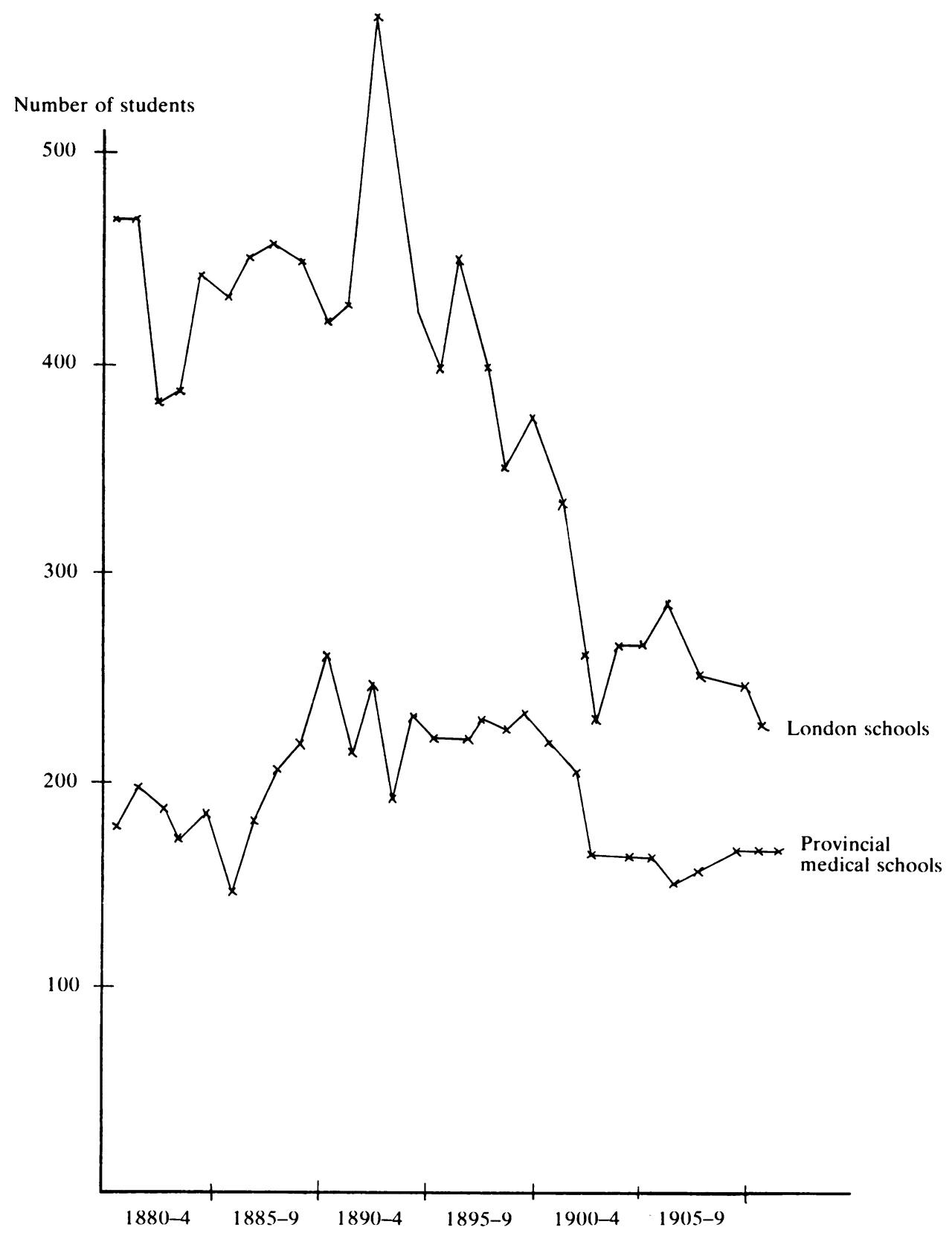

Source: Royal Commission on University Education in London, Fifth Report, London, 1912, (ed. 6312), Appendix 5. 


\section{A transformation in training}

teachers, positively supported these appeals, in some cases donating generously. In Leeds, many doctors were included in the list of donors to the fund to endow the Chair of Physiology. ${ }^{64}$ In Liverpool, Richard Caton, part-time Professor of Physiology 1870-1891, secured funds for a full-time Chair when he resigned to pursue clinical ambitions. The endowment of the pre-clinical sciences enabled doctors to underline publicly the scientific basis of their professional skill. As I have argued elsewhere, doctors did not expect clinical returns on their investment in laboratory research.$^{65}$ Rather, the appointments reflect a more subtle change in the nature of clinical practice. Doctors argued that training in scientific method would produce more proficient practitioners; the bedside and the laboratory were beginning to be seen as analogous spheres. Moreover, within clinical medicine there was greater emphasis on the functional nature of disease. It was therefore important for doctors to understand the normal functions of the body's organ systems. As a result, by the 1900 s, a distinct community of physiologists, anatomists, and pathologists can be distinguished. Members of each discipline communicated their research through established and well-respected national journals: the Journal of Anatomy and Physiology was established in 1866 and later became the journal of the Anatomical Society of Great Britain (founded 1887). The main professional organization for physiology, the Physiological Society, was founded in 1876, and the Journal of Physiology begun two years later; the British Society of Pathology met for the first time in 1906.

\section{CONCLUSIONS}

After 1860, British medical education underwent a gradual revolution. Until the last four decades of the nineteenth century, apprenticeship had been a dominant form of training. From the mid-1860s, however, in response to recommendations from the GMC, which were taken up by the licensing authorities, schools became the central force in professional education. Institutions rather than individuals assumed the role of educators. Students were initiated into the social mores of the profession by the culture of the classroom, laboratory, and sports field rather than through the personal example of a single professional. Apprenticeship was formally abolished by the GMC in 1892.

By situating professional training exclusively in schools, the elaboration of an academic curriculum became possible. Provincial institutions, which had been founded in the 1820 s to provide lecture courses of a supplementary nature to apprenticeship, accommodated to their changing role by associating themselves with neighbouring, newly founded university colleges. As these institutions gained university status, the provincial medical faculties gained the power to award degrees and thus the power to admit to the profession. This transformation from proprietary school to qualifying association was of enormous significance, not least to the provincial universities. Within each movement to secure a university charter, the inclusion of a medical faculty was regarded as vital. Precedents for professional

\footnotetext{
${ }^{64}$ See note 48 above.

${ }^{65}$ Stella V.F. Butler, 'Science and medicine in the nineteenth century: changing conceptions of clinical practice', paper given at a conference on Science and Medicine, Manchester, April 1985.
} 
education (and qualification) as one of the primary functions of universities had been set in Edinburgh in the late-eighteenth and early-nineteenth centuries and in Germany with the reform of the academic system after $1815 .{ }^{66}$ Both these examples were important for those who were concerned to establish a national network of higher education in Britain. By becoming involved in professional training, these nascent institutions secured for themselves a stable and relatively large core of students whose fees ensured vital financial support. As a result of the successes of the provincial colleges in rapidly establishing reputations for efficient teaching and high academic standards, by the 1900 s, British medical education was becoming based in the developing university system. Although Cambridge and Oxford universities became involved again after 1870 in medical education, both concentrated on pre-clinical training and became largely preparatory schools for the London hospitals. ${ }^{67}$ While professional training in London retained its tradition of hospital-based teaching, the precedent set in the provinces stimulated the metropolitan schools to seek a more formal and recognized position within London University. This metropolitan response to the development of the provincial schools indicated their growing strength and the challenge they posed to the domination of the London schools. It is perhaps a peculiarity of British medical education that professional training in London and the provinces has remained distinct in institutional form and tradition. That those distinctions emerged after 1860 indicated both the force behind and the attractiveness of the provincial university medical schools.

\footnotetext{
${ }^{68} \mathrm{G}$. Haines, Essays on German influence upon English education and science, 1850-1919, New Haven, Conn., Yale University Press, 1969.

${ }^{67}$ Gerald L. Geison, Michael Foster and the Cambridge School of Physiology, Princeton University Press, 1978.
} 